THAISZIA

JOURNAL OF BOTANY

\title{
Quercus banatus grows in Slovenia
}

\section{Peter Kučera}

Comenius University in Bratislava, Botanical Garden, workplace Blatnica, Blatnica 315, SK03815 Blatnica pri Martine, Slovakia, peter.kucera@uniba.sk

Kučera P. (2019): Quercus banatus grows in Slovenia. - Thaiszia - J. Bot. 29 (1): 061-069.

Abstract: Occurrence of Quercus banatus P. Kučera (= Q. aurea Wierzb., nom illeg.; Q. dalechampii auct. medioeur. non Ten.) was confirmed in Slovenia during a brief trip to Škocjan Caves in the Škocjan Caves Regional Park (southwestern Slovenia). The species is not recognized in the national Slovenian flora - Mala flora Slovenije, although it was recorded in the Atlas Florae Europaeae (under the name " $Q$. dalechampii"). $Q$. banatus individuals were recently found on two sites: on the slope of a natural bridge between collapse dolines Velika dolina and Mala dolina and on parking lot next to the Park's Information Centre.

Key words: distribution, Quercus, Quercus petraea group, Škocjanske jame.

\section{Introduction}

Quercus banatus P. Kučera ( $=Q$. dalechampii sensu auct. medioeur non Ten., see Discussion) is a tree species widely distributed in the Central Europe and Balkan Peninsula (cf. Fig. 1). Its northern distribution limit reaches more to the north according to newer studies, even to Poland (cf. Požgaj \& Horváthová 1986; Kobližek 1993; Magic 2006); eastwards up to Caucasus (Magic 2006).

However, the newest edition of Mala flora Slovenije recognizes only 10 species of the genus Quercus growing in Slovenia, three of them (including $Q$. frainetto Ten.) as not native species (Martinčič 2007), and, Q. petraea group (= series Sessiliflorae sensu Schwarz 1936a) is there represented only by Q. petraea Liebl. 
and there is no mention of two species of this group, $Q$. polycarpa Schur and Q. dalechampii Ten., accepted in both editions of Flora Europaea (Schwarz 1964, 2010).

Nevertheless, Q. dalechampii Ten. was recorded in Slovenia within the project Atlas Florae Europaeae (Jalas et al. 1976, map 298) with a locality in southwestern Slovenia, the other locality marked close to Sava river between Ljubljana and Zagreb might be from Slovenia as well. Aeschimann et al. (2004) indicate that distribution of this species in the Alpian region of Slovenia should be supplemented.

This contribution presents recent records of $Q$. banatus $P$. Kučera in Slovenia in the area of the Škocjan Caves Regional Park.



Fig. 1. Distribution of Q. banatus according to Atlas Florae Europaeae (Jalas et al. 1976, map 298).

\section{Methods}

GPS coordinates were obtained by application GPS Status \& Toolbox 8.4.177 installed on smartphone Redmi Note 3. Herbarium samples are deposited in the reference herbarium of Comenius University in Bratislava, Botanical Garden, workplace Blatnica (abbreviation BBZ, see Vozárová \& Sutorý 2001). Outline map of Slovenia was provided by www.worldatlas.com. 


\section{Results}

On $2^{\text {nd }}$ September 2018, two sites of occurrence of $Q$. banatus P. Kučera were noted with collaboration of R. Rapant during a short trip to the Škocjan Caves (Škocjanske jame) in Škocjan Caves Regional Park lying in the southwestern part of Slovenia (Fig. 2).

The first noted locality (coordinates $45^{\circ} 39.9580^{\prime} \mathrm{N}, 13^{\circ} 59.4780^{\prime} \mathrm{E}, \pm 10 \mathrm{~m}$ ) is situated in the natural bridge between the collapse dolines Velika dolina and Mala dolina. Two young trees (Fig. 3) grow here directly at the left side of the tourist trail on the upper part of steep slope of the Velika dolina, somewhat below the splitting-up of the trail to the village of Škocjan and the Information Centre of the Škocjan Caves Regional Park.

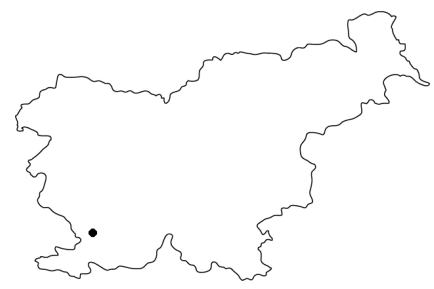

Fig. 2. Localization of the noted occurrence of $Q$. banatus within Slovenia.

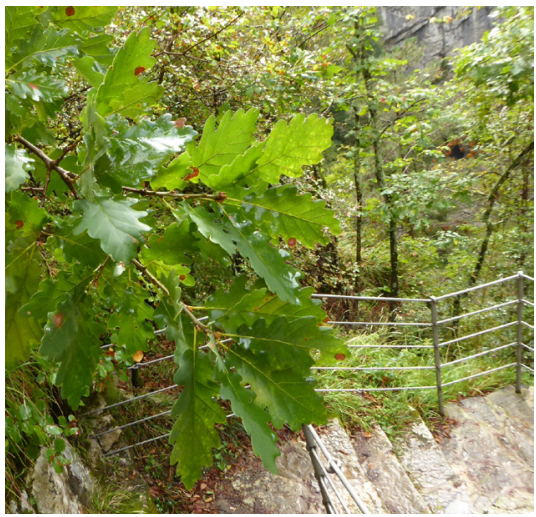

Fig. 3. Q. banatus branch of the individual in the collapse doline Velika dolina.

According to old leaves scattered along the trail towards the Information Centre it is possible that, apart of $Q$. cerris L., other oak individuals presumably related to $Q$. banatus P. Kučera occur in the mixed woodlands of the Škocjan Caves area; however, during our limited time for visit and further shortened by heavy rain any attention could be paid to closer study and documentation of the fallen 
leaves and their possible maternal trees. Nevertheless, the found individuals should undoubtebly be of an autochthonous origin because the steep slopes of the Velika dolina are completely unsuitable for a land management, especially for forest plantations.

The second site of noted $Q$. banatus occurrence (coordinates $45^{\circ} 39.7590^{\prime} \mathrm{N}$, $13^{\circ} 59.3140^{\prime} \mathrm{E}, \pm 3 \mathrm{~m}$ ) is the parking lot next to the Park's Information Centre. Two-stemmed older tree of low height grows in a line of trees dividing the lot into halves differing by their altitude. The individual is not the part of the recent plantation and it is clearly recognizable from a distance by yellowish green colour of its leaves.

Two trunks of this tree indicate that this occurrence might be a remnant of an older tree growing here before; however, it is not sure if the age of that supposed individual would be older than anthropic changes of circumjacent landscape connected with origination and development of the Information Centre of Škocjan Caves Regional Park.

In the direct surroundings of the parking lot and along the starting (above ground) part of the guided tour to the cave of the Reka river (from Information Centre to Globočak) only $Q$. cerris trees were seen, but is possible that $Q$. banatus could be growing there, especially when the species was found in the slope of the collapse doline Velika dolina.

\section{Discussion}

Oak populations of $Q$. banatus have been known under the name $Q$. dalechampii Ten. in the previous literature sources (see below). The latter name has been applied to different taxa in the past which was comprehensively summarized by Di Pietro et al. (2012) - cf. Schwarz (1936a, b, 1937) vs. Camus (1935-1936, 1939). Di Pietro et al. (2012) solved the problem of an inconsistent application of the name $Q$. dalechampii Ten. by designating a lectotype which explicitly belongs to the pubescent oak type (group of $Q$. pubescens Willd.). After this decision, the name $Q$. dalechampii Ten. is no longer applicable for the Central European populations previously classified as $Q$. dalechampii Ten. as well as for the equivalent populations in the Southeastern Europe (cf. Beldie 1952, Gančev \& Bondev 1966).

Therefore, Kučera (2018) proposed a name for Q. dalechampii sensu auct. medioeur. non Ten. $-Q$. banatus P. Kučera (bas. Q. aurea Wierzb. ex Kotschy; syn. Q. aurea Wierzb.), following Schwarz's (1936a) synonymization of “Q. dalechampii Ten." with Q. aurea Wierzb. (cf. also Schwarz 1937, Beldie 1952, Pignatti 1982; or Magic 2006). 
However, it should be noted that careful examination of data referred to as "Q. dalechampii" (= sensu auct. non Ten.) is needed to ensure their adequate taxonomic determination, i.e. identification as either $Q$. banatus P. Kučera or other basic or hybrid/hybridogeneous taxon (within the $Q$. petraea group, or with a taxon from $Q$. robur group or the $Q$. pubescens group; see below).

The occurrence of $Q$. banatus (under the name " $Q$. dalechampii Ten."), is reported in floras from all countries surrounding Slovenia (general data for former Yugoslavia are omitted): Italy (Pignatti 1982), Austria (Adler et al. 1994, Aeschimann et al. 2004), Hungary (Simon 2000, Király et al. 2009-2011), Croatia (Nikolić et al. 2004), also in Serbia (Janković 1970, Kojić 2007). The taxon was included and extensively characterized in national floras of Romania and Bulgaria (Beldie 1952, Gančev \& Bondev 1966) more than half a century ago, following the concept of Schwarz (1937) (cf. also recently Ančev 1992, Sanda et al. 2004, Oprea 2005, Asjov et al. 2012). Q. dalechampii Ten. was also recognized in the territories of Central Europe other than Romanian one (Soó 1964; Mátyás 1967, 1970; Stojko 1969; Futák 1972; Magic 1975; Chopyk et al. 1977) and incorporated in later national floras and handbooks (Soó 1970; Horváthová 1986; Ivčenko 1987; Ciocîrlan 1988; Dostál 1989, 1991; Koblížek 1990, 2002; Didux et al. 2004; Magic 2006; Sârbu et al. 2013, Chopyk \& Fedoronchuk 2015).

I did not found any mentions of " $Q$. dalechampii Ten." in the botanical literature dealing with the region of the Škocjan Caves which would indicate presence of $Q$. banatus $P$. Kučera in this area. In total three oak species were recorded here till the present: Q. cerris L., Q. pubescens Willd. and Q. petraea Liebl. (Grom 1959, Slapnik et al. 2002), Dakskobler 2006, Debevec et al. c2013, Dakskobler et al. 2017; cf. also Zupančič 1999); Morton sec. Tomažič (1946) and Martinčič $(1973,2001)$ did not mention genus Quercus from the area. The online field guide of Debevec et al. (c2013) contains also photographic documentation of the recognized species. However, part of samples labelled as Q. petraea ssp. petraea (mostly from Italian territory) clearly belong to $Q$. pubescens group (incl. hybrid/hybridogeneous taxa) which indicates that knowledge on taxa of the $Q$. petraea group of the region of Škocjan Caves is unsufficient and especially the data on the occurrence of $Q$. petraea s. str. from the other sources should be revised as well.

\section{Acknowledgements}

I am very thankful to R. Rapant for his support and help in field, also to U. Šilc (Ljubljana), N. Rajčević (Belgrade), J. Kochjarová (Zvolen), J. Kliment (Blatnica), P. Mered'a (Bratislava), G. Király (Sopron) and the workers of the Slovak National 
Library (Martin) for help with literature sources. Preparation of this study was partially supported by Slovak grant agency VEGA, project No. 2/0119/19.

\section{References}

Adler W., Oswald K., Fischer R. et al. (1994): Exkursionsflora von Österreich : Bestimmungsbuch füralleinÖsterreich wildwachsenden sowie diewichtigsten kultivierten Gefäßpflanzen (Farnpflanzen und Samenpflanzen) mit Angaben über ihre Ökologie und Verbreitung. - Eugen Ulmer, Wien, Stuttgart.

Aeschimann D., Lauber K., Moser D. M. \& Theurillat J.-P. (2004): Flora alpina : Ein Atlas sämtlicher 4500 Gefäßpflanzen der Alpen. Mit Farbfotografien von Konrad Lauber und Skizzen von André Michel. Band 1, LycopodiaceaeApiaceae. - Haupt Verlag, Bern, Stuttgart, Wien.

Ančev, V. 1992. Bukovi - Fagaceae. - In: Adreev, N., Ančev, M., Kožuxarov, S., Markova, M., Peev, D. et Petrova, A. Opredelitel na visšite rastenija na Bălgarija, p. 441-445. - Nauka i izkustvo, Sofija.

Asjov B., Petrova A. (eds), Dimitrov D. \& Vasilev R. (2012): Konspekt na visšata flora na Bălgarija : Chorologija i florni elementi. 4. rev. upd. ed. - Bălgarska fondacija bioraznoobrazie, Sofija. Available online: https://archive.org/ details/ConspectusOfTheBulgarianVascularFlora.FourthEdition, accessed 5. December 2018

Beldie A. (1952): Fagáceae A. Br. - In: Săvulescu T. (red. princip.), Nyárady E. I. (respons.), Alexandrescu L. et al.: Flora Republicii Populare Române. I., p. 217-260. - Editura Academiei Republicii Populare Române, Bucureşti.

Camus A. (1935-1936): Les chênes. Monographie du genre Quercus. Tome II : Genre Quercus. Sous-genre Euquercus (Section Lepidobalanus). Atlas. - Paul Lechevalier, Paris.

Camus A. (1939): Les chênes. Monographie du genre Quercus. Tome II : Genre Quercus. Sous-genre Euquercus (Sections Lepidobalanus et Macrobalanus). Texte. - Paul Lechevalier, Paris.

Ciocîrlan V. (1988): Flora ilustrată României. Vol. I. Determinarea şi descrierea speciilor spontane şi cultivate. - Editura Ceres, Bucureşti.

Chopyk V. I. \& Fedoronchuk M. I. (2015): Flora Ukrajinskych Karpat. - TzOV «Terno-graf», Ternopil'.

Chopyk V. I., Kotov M. I. \& Protopopova, V. V. (1977): Vyznačnik roslin Ukrajinskych Karpat. -Naukova Dumka, Kyïv.

Dakskobler I. 2006: Prispevek k poznavanju gozdne vegetacije Krasa (jugozahodna Slovenija). - Ann., Ser. Hist. Nat. 16/1: 57-76. Available online: <http://zdjp. si/p/annalesshn/>, accessed 13 September 2018. 
Dakskobler I., Sadar Z. \& Čarni A. 2017: Phytosociological analysis of Quercus cerris woods in the sub-Mediterranean phytogeographical region of Slovenia. - Folia Biol. Geol. 58/2: 5-43. DOI: 10.3986/fbg0026.

Debevec V., Jogan N., Kokalj B., Lozej B., Martellos S., Moro A., Nimis P. L., Šturm S., Zega S. \& Zorman T. (c2013): Rastline Parka Škocjanske jame [online]. - s. n., s. I. Available online: < http://dryades.units.it/skocjanske_si/index. php>, accessed 13 September 2018

Didux Ja. P., Ficajlo T. V. \& Burda R. I. (2004): Quercus dalechampii Ten. Dub Dalešampa. - In: Didux Ja. P. (ed.-in-chief), Burda R. I., Ziman S. M., Korotčenko I. A., Fedorončuk M. M. \& Ficajlo T. V.: Ekoflora Ukraïny. Tom II, p. 425-426. - Kyïv, Fitosociocentr.

Di Pietro R., Viscosi V., Peruzzi L. \& Fortini P. (2012): A review of the application of the name Quercus dalechampii. - Taxon 61/6: $1311-1316$.

Dostál J. (1989): Nová květena ČSSR. 1. - Academia, Praha.

Dostál J. (1991): Vel'ký klúč na určovanie vyšších rastlín. I. Transl. by M. Červenka.

- Slovenské pedagogické nakladatel'stvo, Bratislava.

Futák J. (1972): Fytogeografický prehl'ad Slovenska. - In: Lukniš M. (ed. in-chief), Bako, J., Berta, J., Ferianc, O. et al.: Slovensko. Príroda, p. 431-482. - Obzor, Bratislava.

Gančev I. \& Bondev I. (1966): Dăb - Quercus L. - In: Jordanov D. (ed.-in-chief), Kuzmanov B. (ed.), Asenov I. et al.: Flora na Narodna republika Bălgarija, p. 105-146. - Izdatelstvo na Bălgarskata akademia na naukite, Sofija.

Grom, S. 1959: Prispevek k poznavanju flore v sistemu Škocjanskih jam. - Acta carsol. 2: 251-262.

Horváthová J. (1986): Rozšírenie, variabilita a ekológia zástupcov sekcie Roburoides Schwz., Robur Rchb. a Eucerris Oerst. na Podunajskej nízine. In: Požgaj J. \& Horváthová J.: Variabilita a ekológia druhov rodu Quercus L. na Slovensku. - Acta dendrobiol. [1986]: 69-109.

Ivčenko I. S. (1987): Bukovye (Bukovi) - Fagaceae. - In: Prokudin Ju. N. (ed.), Dobročajeva D. N., Zaveruxa B. V. et al.: Opredelitel' vysšich rastenij Ukrainy, p. 60-61. - Kiev : Naukova Dumka, 1987.

Jalas J., Suominen J. (eds.) (1976): Atlas Florae Europaeae. Distribution of Vascular Plants in Europe. 3. Salicaceae to Balanophoraceae. - The Committee for Mapping the Flora of Europe, Societas Biologica Fennica Vanamo, Helsinki.

Janković M. M. (1970): Red Fagales Dum. - In: Josifović M. (ed.-in-chief), Stjepanović L., Kojić M., Diklić, N. (ed. vol. II) et al.: Flora SR Srbije, II, p. 69-98. - Srpska Akademia Nauka i Umetnosti, Beograd.

Király G. (ed.) et al. (2009-2011): Új magyar füvészkönyv: Magyarország hajtásos növényei. 2 vols. - Aggteleki Nemzeti Park Igazgatóság, Jósvafő. 
Kobližek J. (1990): Fagaceae Dumort. - bukovité. In: Hejný S., Slavík B. (eds), Hrouda L. et al.: Květena České republiky, 2, p. 17-35. - Academia, Praha.

Kobližek J. (1993): Distribution of oak species in the Czech Republic. - Ann. For. Sci. 50/Suppl: 209s-293s. DOI: 10.1051/forest:19930729

Koblížek J. (2002): Quercus L. - dub. - In: Kubát K. (ed.-in-chief), Hrouda L., Chrtek J. jun. et al.: Klíč ke květeně České republiky, p. 141-143. - Academia, Praha. Kojić M. (2007): Ekskursiona flora Srbije. - NNK international, Beograd.

Kučera P. (2018): New name for Central Europaean oak formerly labelled as Quercus dalechampii. - Biologia (Bratislava) 73/4: 313-317. DOI: 10.2478/ s11756-018-0048-z.

Magic D. (1975): Taxonomické poznámky z doterajšieho výskumu dubov v Západných Karpatoch. - Biológia (Bratislava) 30/1: 65-74.

Magic D. (2006): Quercus L. exp. consult. J. Májovský, J. Michalko. - In: Goliašová K., Michalková E. (eds), Benčat' F. et al.: Flóra Slovenska, V/3, p. 108-143.VEDA, vydavatel'stvo Slovenskej akadémie, Bratislava.

Martinčič A. (1973): Reliktna flora v Škocjanskih jamah in njena ekologija. - Biol. vestnik 21/2: 117-126.

Martinčič A. (2001): Škocjanske jame pri Divači. Flora, vegetacija, ekologia. In: Čarni A. (ed.).: Vegetacija Slovenije in sosednjih območij 2001, p. 110126. - Botanično društvo Slovenije, Biološki ištitut Jovana Hadžija ZRC SAZU, Ljubljana.

Martinčič A. (2007): Fagaceae - bukvovke. - In: Martinčič A. (ed.), Wraber T., Jogan N. et al.: Mala flora Slovenije : Ključ za določanje praprotnic in semenk. 4., dopolnj. spremenj. izd., p. 221-223. - Tehniška založba Slovenije, Ljubljana.

Mátyás V. (1967): A tölgyek dendrológiai ismertetése. - In: Keresztesi B. (ed.). A tölgyek, p. 51-90. - Akadémiai Kiadó, Budapest.

Mátyás V. (1970): Taxa nova Quercuum Hungariae. - Acta Bot. Acad. Sci. Hung. 16/3-4: 329-361.

Nikolić T. (ed.) et al. (2004): Flora Croatica Database. - Botanički zavod, PMF, FERZPR, Sveučilište u Zagrebu, Zagreb, actualiz. 17. 2. 2018. Available online: $<$ http://hirc.botanic.hr/fcd>, accessed 13 September 2018.

Oprea A. (2005): Lista critică a plantelor vasculare din România. - Editura Universității „Alexandru Ioan Cuza“, Iaşi.

Pignatti S. (1982): Quercus L. - Quercia (1893). In: Pignatti S. (ed.) et al.: Flora d' Italia. Vol. 1, p. 113-120. - Edagricole, Bologna.

Požgaj J. \& Horváthová J. (1986): Variabilita a ekológia druhov rodu Quercus L. na Slovensku. - Acta dendrobiol. [1986]: 152 pp.

Sanda V., Barabaş N. \& Ştefănuț S. (2004): Atlas Florae Romaniae. III. Genul Quercus. - Editura "Ion Borcea”, Bacău. 
Sârbu I., Ştefan N. \& Oprea A. (2013): Plante Vasculare din România : Determinator ilustrat de teren. - Editura Victor B Victor , Bucureşti.

Schwarz O. (1936a): Entwurf zu einem natürlichen System der Cupuliferen und der Gattung Quercus L. - Notizbl. Königl. Bot. Gart. Berlin XIII/116: 1-22. DOI: $10.2307 / 3994908$.

Schwarz O. (1936b): Monographie der Eichen Europas und des Mittelmeergebietes. II., Atlas der Blattformen. Lieferung 1. - Repert. Spec. Nov. Regni Veg., Sonderbeih. D: 2 pp., tab. I-XVI.

Schwarz O. (1937): Monographie der Eichen Europas und des Mittelmeergebietes. I., Textband [Lief. 1/5]. - Repert. Spec. Nov. Regni Veg., Sonderbeih. D: $200 \mathrm{pp}$.

Schwarz O. (1964): Quercus L. - In: Tutin T. G., Heywood V. H., Burges N. A. (eds) et al.: Flora Europaea. Vol. 1. Lycopodiaceae to Platanaceae, p. 61-64. - University Press, Cambridge.

Schwarz O. (2010): Quercus L. - In: Tutin T. G., Burges N. A., Chater A. O. (eds) et al.: Flora Europaea, 2. ed., Vol. 1, Psilotaceae to Platanaceae, p. 72-76. - Cambridge University Press, Cambridge.

Simon T. (2000): A Magyarországi edényes flóra határozója : harasztok - virágos növények. 4. rev. ed. - Nemzeti tankönyvkiadó, Budapest.

Slapnik R. (ed.), Čarni A., Čelik T., Čušin B., Dakskobler I., Drovenik B., Pirnat A., Seliškar A., Surina B. \& Vreš B. (2002): Flora, favna in vegetacija regijskega parka Škocjanske jame : elaborat. - Biološki inštitut Jovana Hadžja, Znanstvenoraziskalni center SAZU, Ljubljana.

Soó R. (1964): A magyar flóra és vegetáció rendszertani-növényföldrajzi kézikönyve I. - Akadémiai Kiadó, Budapest.

Soó, R. (1970): A magyar flóra és vegetáció rendszertani-növényföldrajzi kézikönyve IV. - Akadémiai Kiadó, Budapest.

Stojko S. M. (1969): Dubovye lesa karpatskoj gornoj sistemy. - s. n., Kiev. Dissertation review.

Tomažič G. (1946): Flora in vegetacija kraških jam. - Zborn. Prirodoslov. Društva 4: 74-78, tab. suppl.

Vozárová M. \& Sutorý K. (2001): Index herbariorum Reipublicae bohemicae et Reipublicae slovacae. - Zprávy České Bot. Společn. 36/Přiloha 2001/1, Bull. Slov. Bot. Spoločn. 23/Supl. 7: 96 p.

Zupančič M. (1999): Gozdna in grmiščna vegetacija krasa. - In: Kranjc A., Likar V., Huzjan M. Ž. (eds) et al.: Kras - pokrajina, življenje, ljudje, p. 114-123. - Inštitut za raziskovanje krasa ZRC SAZU, Ljubljana. 